\title{
Media competition and information disclosure
}

\author{
Ascensión Andina-Díaz
}

Published online: 29 January 2009

(C) Springer-Verlag 2009

\section{Erratum to: Soc Choice Welf DOI 10.1007/s00355-008-0356-2}

Unfortunately, some typos in the acknowledgment remained uncorrected. The correct version is given below:

Acknowledgments This paper is based on Chap. 2 of my Ph.D. thesis completed at Universidad de Alicante under the helpful supervision of Javier M. López-Cuñat.A previous version of this paper circulated with the title "Asymmetric information and Election campaigns: the monitoring role of media" (IVIE WP-AD 2004-32). I thank Enriqueta Aragonés, Timothy Besley, Matthias Dahm, Daniel Diermeier, Ramón Faulí, Timothy Feddersen, Bard Harstad, Sanjeev Goyal, Miguel A. Meléndez-Jiménez, Ignacio Ortuño-Ortín, Christian Schultz, David Strömberg, the associate editor and seminar audiences at MEDS Northwestern University, University of Munich, Universidad de Murcia, Universidad Autónoma de Madrid, Universidad de Alicante, SAE Sevilla, ASSET Ankara, EEA Stockholm and SMYE Leuven for valuable comments and suggestions. The hospitality of Queen Mary, University of London, and Kellogg School of Management, Northwestern University, were part of this research was carried out, is gratefully acknowledged.

The publisher apologizes for any inconvenience caused by this mistake.

The online version of the original article can be found under doi:10.1007/s00355-008-0356-2.

A. Andina-Díaz $(\varangle)$

Dpto Teoría e Historia Económica, Campus de El Ejido, Universidad de Málaga, 29071 Málaga, Spain e-mail: aandina@uma.es 